\title{
Adansonia digitata germination tests. Elephants or heat: what causes scarification of seed to facilitate germination?
}

\author{
Thea Lautenschläger ${ }^{*} \mathbb{B}$, Nele Teutloff, Markus Günther and Christoph Neinhuis
}

\begin{abstract}
Background: The dormancy of Adansonia digitata seeds is well known. For propagation purposes, plenty of germination tests were conducted, however, rarely taking the ecology of baobab into account. Our main goal, therefore, is to identify the decisive natural trigger for breaking the dormancy. We therefore performed 31 different tests and their influence on the germination rate (time to germination and proportion of seeds germinating).

Results: The highest germination rates were reached in the heat tests while elephant's digestion seems to stimulate germination of Adansonia digitata only to a limited extent. The chalazal slit of the seed represents the primary site of water entry. Tannins concentrated in this region that are influenced by temperature play an important role for inhibiting the germination.

Conclusion: As a result, the hypothesis is formulated that germination success strongly depends on heat, provoked by wildfires or prolonged exposition to the sun causing decomposition of tannins by high temperatures rather than on digestion.
\end{abstract}

Keywords: Seed dormancy, Seed coat, Acid, Digestion, Heat, Fire, Soil temperature, Solar radiation, Scarification

\section{Introduction}

Seeds of Adansonia digitata L. (Malvaceae) possess a thick and firm testa. Protective tissues of large seeds are known to increase survival in fire-prone savanna (Gashaw and Michelsen 2002) but at the same time impede germination under normal conditions. The dormancy of $A$. digitata seeds released from ripe fruits imposed by their hard seed coats is well known (Niang et al. 2015) as seeds exhibit water-impermeable coats (Razanameharizaka et al. 2006) and a high amount of tannin between the chalazal cap and the embryo was described (Rao 1954). Several authors carried out germination tests on A. digitata seeds for conservation purposes (Esenowo 1991; Johansson 1999; Razanameharizaka et al. 2006; Niang et al. 2015; El-bably and Rashed 2018). To this effect,

\footnotetext{
*Correspondence: thea.lautenschlaeger@tu-dresden.de Department of Biology, Institute of Botany, Faculty of Science, Technische Universität Dresden, Dresden 01062, Germany
}

different test set-ups were used to allow scarification imitating digestion or heat processes. On the one hand, it is to be presumed that the passage through the digestive tract improves germination because it softens the testa and enhances water absorption (Chevalier 1906; Gebauer El-Siddig and Ebert 2002; McGrew et al. 2003), but for $A$. digitata reliable information is still lacking (Wickens and Lowe 2008). However, it was also found that the fruit pulp acts as a germination inhibitor (Esenowo 1991) so that it seems quite reasonable to assume that digestion could have a positive effect.

Regarding the impact of heat, several studies included a seed treatment in cold, hot or even boiling water (Esenowo, 1991; Razanameharizaka et al. 2006; Niang et al. 2015) but only Johansson (1999) studied the influence of dry heat on germination applying temperatures of $100{ }^{\circ} \mathrm{C}$ and $250{ }^{\circ} \mathrm{C}$ only. In this study, we therefore focused on a variety of heat treatments, which most probably occur in baobabs natural habitat. We wanted to clarify whether 
scarification of seed testa is more favourable using "digestive" methods or by heat impact. Heat treatments comprised not only wet but also dry heat at different temperatures to identify the range resulting in the highest germination rate and then contextualize the data to its ecological equivalent such as solar radiation, heating up the soil or heat caused by wildfires. Furthermore, we state different explanation attempts regarding the opening process during germination of the Adansonia seed because former studies on water gaps in seeds consider only anatomical details without taking into account the various factors inhibiting germination (Rao 1954; Corner 1976; Gama-Arachchige et al. 2013).

\section{Materials and methods}

Six germination test sets were conducted, two in 2017 with 2 month of temporal distance, one test in 2018, two in 2019 and one in 2020. For every test set, seeds taken from ten fruits of $A$. digitata were used. These fruits were bought at the local central market in Uíge in northern Angola (S 7 $7^{\circ} 36^{\prime} 48^{\prime \prime}$, E 15 $03^{\prime} 27^{\prime \prime}$ ) in March 2016, February 2018 and April 2019.

All test sets differed from each other and were derived from previous experiments (Esenowo 1991; Johansson 1999; Razanameharizaka et al. 2006). While in 2017 only five variables for each attempt were tested (elephants' digestion, $70{ }^{\circ} \mathrm{C}$ hot water for $40 \mathrm{~min}, 3$ days cold water, $10 \mathrm{~min}$ in $\mathrm{H}_{2} \mathrm{SO}_{4}$, and no treatment) the test sets in 2018 , 2019 and 2020 were expanded considerably.

To allow scarification by the digestive system of predators, fruits were opened and the fruit pulp with the embedded seeds was fed to three elephants (Loxodonta africana) in the Zoological Garden Dresden. Twentyeight to $36 \mathrm{~h}$ later, seeds were picked out of the dung and concurrently sowed. In the 2018 test set, seeds were additionally sowed in the dung in which they were embedded. In 2019, elephant's digestion and heat treatment were combined by picking the seeds from the dung subsequently exposing them to heat of $75{ }^{\circ} \mathrm{C}, 100{ }^{\circ} \mathrm{C}$, $125^{\circ} \mathrm{C}$ and $150{ }^{\circ} \mathrm{C}$ for $5 \mathrm{~min}$. As chemical acids are often mentioned to imitate this intestinal scarification process, we also included this treatment by soaking the seeds in concentrated $\mathrm{H}_{2} \mathrm{SO}_{4}(\mathrm{pH} 1,73)$ for $10 \mathrm{~min}$ in 2017 or rather 5, 10 and $15 \mathrm{~min}$ in 2018 with subsequent rinsing in running water for $3 \mathrm{~h}$. We decided to use this method because Esenowo (1991) achieved the best results using $\mathrm{H}_{2} \mathrm{SO}_{4}$. Furthermore, we treated seeds with $\mathrm{HCl}$ of $\mathrm{pH} 2$ and 3 for 1 or $2 \mathrm{~h}$ in 2019 as it most likely mimics gastric juice, which exhibits a pH value of 2-3 (Van Howen, Prins and Lankhorst 1981; Prenzlin 2009).

To detect the influence of heat, seeds were put into $70{ }^{\circ} \mathrm{C}$ hot water for $40 \mathrm{~min}$, using a thermos flask to keep temperature constant. This temperature and time of exposure was recommended by Esenowo (1991). In the amplified test set, we included dry and moist heat with varying temperatures using a stove (AEG Competence PNC 944). For the dry heat, seeds were exposed to heat of $50{ }^{\circ} \mathrm{C}, 75^{\circ} \mathrm{C}, 150{ }^{\circ} \mathrm{C}$ and $125^{\circ} \mathrm{C}$ for 40 min each, whereas for the moist conditions seeds were imbedded in wet sand and then put into the oven. We expanded the test set in 2019 with dry heat of $75{ }^{\circ} \mathrm{C}, 100{ }^{\circ} \mathrm{C}, 125$ ${ }^{\circ} \mathrm{C}$ and $150{ }^{\circ} \mathrm{C}$ for $5 \mathrm{~min}$. These selected temperatures as well as the exposure time was adapted from Kempe et al. (2018) orienting to several studies on wildfire intensities (Trollope 1984; Miranda et al. 1993; Savadogo et al. 2007). One control was done with seeds put in cold water $\left(20{ }^{\circ} \mathrm{C}\right)$ for 3 days (Johansson 1999), one negative control without any treatment, and additionally one control without treatment but sowed in the Botanic Garden in Uíge, Angola to verify $A$. digitata germination results within the natural range of the tree. As a positive control, we incorporated a manual nicking treatment (Table 1). Derived from Razanameharizaka et al. (2006), we carried out these germination tests according to ISTA (International Seed Testing Association 1999). Therefore, small parts of the seed coat $\left(5-10 \mathrm{~mm}^{2}\right)$ were first removed using pruning shears and then sowed in sterilized sand, moistened with distilled water. The germination boxes were stored at $30 \pm 1{ }^{\circ} \mathrm{C}$ in a dark atmosphere of an incubator (Sanyo Incubator MIR-253) for 25 days. We considered a seed germinated if the radicle emerged through the seed coat.

One hundred seeds of each experimental variant were used excepted for the combination of elephant's digestion and heat treatment where the picked seeds in faeces just sufficed for 50 seeds per experiment. Apart from the elephant variant, fruit pulp was removed from all seeds by rubbing the seeds between hands because the pulp was proven to impede germination (Esenowo 1991; Johansson 1999). Thus, in total five variants each in two settings with in total 1.000 seeds in 2017, 16 variants with in total 1.600 seeds in 2018, 17 variants with 100 seeds, 4 variants with 50 seeds with in total 1.900 seeds in 2019 and 100 seeds in 2020 were used for germination tests.

Cultivation took place in a greenhouse of the Botanical Garden of the TU Dresden (average temperature of $21{ }^{\circ} \mathrm{C}$ and an average humidity of $82 \%$ ) from the beginning of February to the end of September 2017, from beginning of March to end of end of June 2018 and from mid-February to the end of September 2019, respectively. According to sunrise and sunset, day lengths vary from $9 \mathrm{~h}$ in February and September to $16.5 \mathrm{~h}$ in June (http:// www.sunrise-set.com). Seeds were irrigated every day. Successful germination was detected every day, except on weekends. Germination rates were clustered in 2-week periods. Recording of the germination success focussed 
on the first 10 weeks since we observed in 2017 that the influence of the treatments was noticeable only in the first 8 weeks, while later germination occurred only randomly (maximum 1 of 100 seeds per 4 weeks). This was proven by statistical analysis via student's t-test (McDonald, 2015). Gashaw and Michelsen (2002) recorded germination rates of different Ethiopian woody savanna plant seeds after heat treatment for 9 weeks only, because thereafter no additional seedlings emerged while Razanameharizaka et al. (2006) documented germination rate only for 25 days. At the end of the experiment, germination counts were calculated in percentages (\%). We checked whether treated seeds germinated significantly better than seeds without treatment using the Chi square-test of independence (McDonald 2015).

Furthermore, for seed morphometric comparisons with other germination studies, length of 20 seeds and 100seed dry weight was documented. For seed length, a digital calliper with an accuracy of $0.1 \mathrm{~mm}$ was used. Weight was measured using an electronic balance (maximum $=$ $81 \mathrm{~g} / 200 \mathrm{~g}, \mathrm{~d}=0.01 \mathrm{mg} / 0.1 \mathrm{mg}$, model Mettler Toledo XA 205 DualRange). A scanning electron microscope (SEM; Zeiss Supra 40VP, Ulm, Germany) was used for studying the seed coat. The X-ray computerized tomography was equipped with a micro-focus tube and a CCD sensor taking pictures at $60 \mathrm{kV}$ and a current of $200 \mu \mathrm{A}$.

\section{Results}

\section{Germination tests}

Scarification processes are important factors influencing germination rate (GR) as already proven earlier (Esenowo 1991; Razanameharizaka et al. 2006; Niang et al. 2015). As expected, seeds that were sowed without any treatment did not germinate, which again confirmed earlier results and can be explained by the dormancy of Adansonia digitata seeds and their thick testa of about $700 \mu \mathrm{m}$ (Fig. 2a).

The test "digestion by elephants" only reached an average GR of $2.7 \%$ that still resulted in a significant increase of the GR $(\mathrm{P}<0.05)$. Whether seeds were sown in soil or in elephant's faeces did not make a difference. Although the treatment with concentrated $\mathrm{H}_{2} \mathrm{SO}_{4}$ for 5, 10 and 15 min showed an increased GR with a maximum of $14 \%$ after 15 min exposure time these data are in strong contrast to the data obtained by Esenowo (1991) who reported a GR of $98 \%$ after $15 \mathrm{~min}$ in $\mathrm{H}_{2} \mathrm{SO}_{4}$. The treatment with $\mathrm{HCL} \mathrm{pH}=2$ as well as $\mathrm{pH}=3$ for 1 or $2 \mathrm{~h}$ also confirm a low GR generated through acid treatment $(0-2 \%)$. Seeds digested by an elephant before heat treatment show a significantly lower GR at temperatures of $75{ }^{\circ} \mathrm{C}$ and $100{ }^{\circ} \mathrm{C}$ for 5 min than seeds only treated with heat $(\mathrm{P}<0.01)$. The germination rates of the acid treatments are shown in Table 2.

Due to these results, we subsequently concentrated on heat impact and wanted to know whether higher temperatures may be responsible for the breaking seed dormancy and, if so, what the relevant temperature range may be. Heat treatment for a short period of time like 5 min shows a really high GR for $75^{\circ} \mathrm{C}$ and $100{ }^{\circ} \mathrm{C}$ with a maximum of $78 \%$ at $100{ }^{\circ} \mathrm{C}$. Apparently, the temperature is high enough to break the seed dormancy efficiently and the time short enough not to kill the embryo. While heat treatment under dry conditions above $100{ }^{\circ} \mathrm{C}$ for $40 \mathrm{~min}$ did not show any germination, presumably because the embryo was killed, temperatures $\leq 75{ }^{\circ} \mathrm{C}$ revealed significantly higher GR as compared to the control. $50{ }^{\circ} \mathrm{C}$ resulted in just a small but significant increase by $13 \% \mathrm{GR}$ $(\mathrm{P}<0.01)$, while $\mathrm{GR}$ at $75{ }^{\circ} \mathrm{C}$ raised to $64 \%$ GR $(\mathrm{P}<0.01)$. The seeds treated under wet conditions (wet sand) germinated at even higher rates: $75^{\circ} \mathrm{C}$ resulted in $72 \%$ GR. But again $100{ }^{\circ} \mathrm{C}$ most probably killed the embryos and no germination was observed. The germination rates of the different heat treatments are shown in Table 3. However, not only temperature determinate a border for breaking seed dormancy, also time of heat treatment seems to play an important role. Interestingly, the temporal progressions of germination differed between dry and wet heat. While the majority of seeds treated with hot water for $40 \mathrm{~min}$ or in wet hot sand germinated in the 3rd and 4th week after the treatment, those treated under dry conditions germinated 2 weeks later on average.

Soaking the seeds during 3 days in cold water did not increase GR although Johansson (1999) stated that soaking in cold water for 3 days would break seed dormancy

Table 1 Control test setups: Relative germination rate of Adansonia digitata seeds after 10 weeks [\%]

\begin{tabular}{|c|c|c|c|c|c|}
\hline Treatment & $2017 a$ & 2017b & 2018 & $2019 a / 2020$ & Average \\
\hline Negative control: no treatment & 1 & 0 & 0 & 3 & 1 \\
\hline No treatment, planted in sun in Angola & & 0 & & 13 & $13^{* *}$ \\
\hline No treatment, planted in shadow in Angola & & & & 0 & 0 \\
\hline Positive control: manual nicking treatment & & & & 74 & $74^{* *}$ \\
\hline
\end{tabular}

Results obtained in three test setups with 100 seeds per treatment each: 2017a, 2017b, 2018 and 2019a. Significant increase of GR compared to the control without treatment are indicated with ${ }^{*} \mathrm{P}<0.05$, ${ }^{* *} \mathrm{P}<0.01$ 
Table 2 Acid treatment: relative germination rate of Adansonia digitata seeds after 10 weeks [\%]

\begin{tabular}{|c|c|c|c|c|c|}
\hline Treatment & $2017 a$ & $2017 b$ & 2018 & 2019a & Average \\
\hline $\mathrm{H}_{2} \mathrm{SO}_{4}$ for 5 min & & & 0 & & 0 \\
\hline $\mathrm{H}_{2} \mathrm{SO}_{4}$ for 10 min & 12 & 7 & 3 & & $7.3^{* *}$ \\
\hline $\mathrm{H}_{2} \mathrm{SO}_{4}$ for $15 \mathrm{~min}$ & & & 14 & & $14^{* *}$ \\
\hline $\mathrm{HCl}$ for $1 \mathrm{~h}, \mathrm{pH} 2$ & & & & 0 & 0 \\
\hline $\mathrm{HCl}$ for $1 \mathrm{~h}, \mathrm{pH} 3$ & & & & 2 & 2 \\
\hline $\mathrm{HCl}$ for $2 \mathrm{~h}, \mathrm{pH} 2$ & & & & 1 & 1 \\
\hline $\mathrm{HCl}$ for $2 \mathrm{~h}, \mathrm{pH} 3$ & & & & 2 & 2 \\
\hline Elephants' digestion, germinating in soil & 0 & 7 & 1 & & $2.7^{*}$ \\
\hline $\begin{array}{l}\text { Elephants' digestion, germinating in elephants' } \\
\text { faeces }\end{array}$ & & & 1 & & 1 \\
\hline
\end{tabular}

Results obtained in three test setups with 100 seeds per treatment each: 2017a, 2017b, 2018 and 2019a. Significant increase of GR compared to the control without treatment are indicated with ${ }^{*} \mathrm{P}<0.05,{ }^{*} \mathrm{P}<0.01$

Table 3 Heat treatment: Relative germination rate of Adansonia digitata seeds after 10 weeks [\%]

\begin{tabular}{|c|c|c|c|c|c|}
\hline Treatment & $2017 a$ & $2017 b$ & 2018 & $2019 b / 2020$ & Average \\
\hline Cold water for 3 days & 0 & 1 & 0 & & 0.3 \\
\hline In hot water for $40 \mathrm{~min} 70^{\circ} \mathrm{C}$ & 70 & 73 & 42 & 63 & $62^{* *}$ \\
\hline \multicolumn{6}{|l|}{ Short-time heat treatment } \\
\hline In oven for $5 \min 75^{\circ} \mathrm{C}$ & & & & 51 & $51^{* *}$ \\
\hline In oven for $5 \min 100^{\circ} \mathrm{C}$ & & & & 78 & $78^{* *}$ \\
\hline In oven for $5 \min 125^{\circ} \mathrm{C}$ & & & & 11 & $11^{* *}$ \\
\hline In oven for $5 \min 150^{\circ} \mathrm{C}$ & & & & 3 & 3 \\
\hline \multicolumn{6}{|l|}{ Long-time heat treatment } \\
\hline In oven for $40 \min 50^{\circ} \mathrm{C}$ & & & 13 & & $13^{* *}$ \\
\hline In oven for $40 \mathrm{~min} 75^{\circ} \mathrm{C}$ & & & 64 & & $64^{* *}$ \\
\hline In oven for $40 \mathrm{~min} 100^{\circ} \mathrm{C}$ & & & 0 & & 0 \\
\hline In oven for $40 \min 125^{\circ} \mathrm{C}$ & & & 0 & & 0 \\
\hline In wet sand in oven for $40 \min 50^{\circ} \mathrm{C}$ & & & 8 & & $8^{* *}$ \\
\hline In wet sand in oven for $40 \mathrm{~min} 75^{\circ} \mathrm{C}$ & & & 72 & & $72^{* *}$ \\
\hline In wet sand in oven for $40 \mathrm{~min} 100^{\circ} \mathrm{C}$ & & & 0 & & 0 \\
\hline In wet sand in oven for $40 \mathrm{~min} 125^{\circ} \mathrm{C}$ & & & 0 & & 0 \\
\hline \multicolumn{6}{|c|}{ Combination of elephants' digestion and heat treatment } \\
\hline Elephants' digestion + in oven $5 \min 75^{\circ} \mathrm{C}$ & & & & 24 & $24^{* *}$ \\
\hline Elephants' digestion + in oven $5 \min 100^{\circ} \mathrm{C}$ & & & & 28 & $28^{* *}$ \\
\hline Elephants' digestion + in oven $5 \min 125^{\circ} \mathrm{C}$ & & & & 16 & $16^{* *}$ \\
\hline Elephants' digestion + in oven $5 \min 150^{\circ} \mathrm{C}$ & & & & 4 & $4^{*}$ \\
\hline
\end{tabular}

Results obtained in three test setups with 100 seeds per treatment each, except 50 seeds for combination of elephant's digestion and heat treatment: 2017a, 2017b, 2018 and 2019b. Significant increase of GR compared to the control without treatment are indicated with ${ }^{*} P<0.05,{ }^{* *} P<0.01$

of $A$. digitata without further treatment. Nevertheless, with a maximum of $60 \%$ the GR in her experiments were comparatively low.

\section{Temporal progress of germination}

The student's t-test showed that after 8 weeks significantly less germination occurs than during the first eight weeks (2017a: $\mathrm{t}=1.58$, d.f.4, $\mathrm{P}=0.18 ; 2017 \mathrm{~b}$ : $\mathrm{t}=1.0$, d.f.4, $\mathrm{P}=0.37)$. Within that time, several periods of germination were observed, depending on seed treatment (Tables 4 and 5). In general, GR during the first 2 weeks and after the 6th week is low. Most of seeds treated with $\mathrm{H}_{2} \mathrm{SO}_{4}, \mathrm{HCl}$ or digested by elephants germinated within the third and 4th week. Looking at the heat treatments, the germination behaviour differs as follows: after treatments in hot water or wet hot sand 
Table 4 Acid treatment: Relative germination rate of Adansonia digitata seeds in percentage

\begin{tabular}{|c|c|c|c|c|c|}
\hline Treatment & $0-2$ weeks & 3-4 weeks & 5-6 weeks & $7-8$ weeks & 9-10 weeks \\
\hline $\mathrm{H}_{2} \mathrm{SO}_{4}$ for 5 min & 0 & 0 & 0 & 0 & 0 \\
\hline $\mathrm{H}_{2} \mathrm{SO}_{4}$ for $10 \mathrm{~min}$ & $0.3^{\mathrm{a}}$ & $5.7^{\mathrm{a}}$ & $1^{\mathrm{a}}$ & $0^{\mathrm{a}}$ & $0.3^{\mathrm{a}}$ \\
\hline $\mathrm{H}_{2} \mathrm{SO}_{4}$ for $15 \mathrm{~min}$ & 2 & 12 & 0 & 0 & 0 \\
\hline $\mathrm{HCl}$ for $1 \mathrm{~h}, \mathrm{pH} 2$ & 0 & 0 & 0 & 0 & 0 \\
\hline $\mathrm{HCl}$ for $1 \mathrm{~h}, \mathrm{pH} 3$ & 0 & 0 & 1 & 1 & 0 \\
\hline $\mathrm{HCl}$ for $2 \mathrm{~h}, \mathrm{pH} 2$ & 0 & 1 & 0 & 0 & 0 \\
\hline $\mathrm{HCl}$ for $2 \mathrm{~h}, \mathrm{pH} 3$ & 0 & 2 & 0 & 0 & 0 \\
\hline Elephants' digestion, germinating in soil & $0.7^{\mathrm{a}}$ & $1.7^{\mathrm{a}}$ & $0^{\mathrm{a}}$ & $0.3^{\mathrm{a}}$ & $0^{\mathrm{a}}$ \\
\hline $\begin{array}{l}\text { Elephants' digestion, germinating in elephants' } \\
\text { faeces }\end{array}$ & 0 & 1 & 0 & 0 & 0 \\
\hline
\end{tabular}

Numbers marked with ${ }^{a}$ are the average of the germination tests $(2017,2018,2019)$ the remaining numbers are obtained in the test sets in 2018 or 2019

Table 5 Heat treatment: Relative germination rate of Adansonia digitata seeds in percentage

\begin{tabular}{|c|c|c|c|c|c|}
\hline Treatment & $0-2$ weeks & 3-4 weeks & 5-6 weeks & 7-8 weeks & 9-10 weeks \\
\hline \multicolumn{6}{|l|}{ Short-time heat treatment } \\
\hline In oven for $5 \min 75^{\circ} \mathrm{C}$ & 0 & 26 & 21 & 4 & 0 \\
\hline In oven for $5 \min 100^{\circ} \mathrm{C}$ & 0 & 35 & 42 & 1 & 0 \\
\hline In oven for $5 \min 125^{\circ} \mathrm{C}$ & 0 & 5 & 4 & 2 & 0 \\
\hline In oven for $5 \min 150^{\circ} \mathrm{C}$ & 0 & 0 & 3 & 0 & 0 \\
\hline \multicolumn{6}{|l|}{ Long-time heat treatment } \\
\hline In oven for $40 \min 50^{\circ} \mathrm{C}$ & 0 & 6 & 6 & 1 & 0 \\
\hline In oven for $40 \min 75^{\circ} \mathrm{C}$ & 0 & 19 & 45 & 0 & 0 \\
\hline In oven for $40 \mathrm{~min} 100^{\circ} \mathrm{C}$ & 0 & 0 & 0 & 0 & 0 \\
\hline In oven for $40 \min 125^{\circ} \mathrm{C}$ & 0 & 0 & 0 & 0 & 0 \\
\hline In wet sand in oven for $40 \mathrm{~min} 50^{\circ} \mathrm{C}$ & 0 & 2 & 6 & 0 & 0 \\
\hline In wet sand in oven for $40 \mathrm{~min} 75^{\circ} \mathrm{C}$ & 5 & 46 & 21 & 0 & 0 \\
\hline In wet sand in oven for $40 \mathrm{~min} 100^{\circ} \mathrm{C}$ & 0 & 0 & 0 & 0 & 0 \\
\hline In wet sand in oven for $40 \min 125^{\circ} \mathrm{C}$ & 0 & 0 & 0 & 0 & 0 \\
\hline \multicolumn{6}{|c|}{ Combination of elephants' digestion and heat treatment } \\
\hline Elephants digestion + in oven $5 \min 75^{\circ} \mathrm{C}$ & 2 & 12 & 10 & 0 & 0 \\
\hline Elephants' digestion + in oven $5 \min 100^{\circ} \mathrm{C}$ & 0 & 18 & 10 & 0 & 0 \\
\hline Elephants' digestion + in oven $5 \min 125^{\circ} \mathrm{C}$ & 0 & 8 & 8 & 0 & 0 \\
\hline Elephants' digestion + in oven $5 \min 150^{\circ} \mathrm{C}$ & 2 & 2 & 0 & 0 & 0 \\
\hline
\end{tabular}

Numbers marked with are the average of the germination tests $(2017,2018,2019)$ the remaining numbers are obtained in the test sets in 2018 or 2019

for 40 min rapid germination occurred in week 3 and 4 while it was delayed by 2 weeks after exposure to dry hot sand (Fig. 1). In 2018, 95\% of the germinated seeds treated with hot water germinated in week $3-4,64 \%$ of those treated with wet sand $\left(75^{\circ} \mathrm{C}\right)$, but just $30 \%$ of the seed treated in dry heat $\left(75^{\circ} \mathrm{C}\right)$. The latter showed the main germination peak in week 5-6 (70\%). At lower temperature $\left(50{ }^{\circ} \mathrm{C}\right)$ this trend slows down but is still significant $(\mathrm{P}<0.01)$. The temporal progress of the different tests is shown in the Additional file 1.

\section{Seed morphometrics}

The average length of $A$. digitata seeds collected in northern Angola is $12.0 \pm 0.39 \mathrm{~mm}$. The 100-seed dry weight is $53.75 \mathrm{~g}$.

\section{Visualization of testa and germination process}

The seed coat of Adansonia digitata seeds is shown in Fig. 2a. It is composed of the $6-8$ celled testa, and the tegmen whose exotegmen consists of exceptionally long Malpighian cells with a distinct light line forming an up to $1 \mathrm{~mm}$ high palisade layer (Rao 1954; Corner 1976). Furthermore, an inner pigment layer exhibits cell lumen 


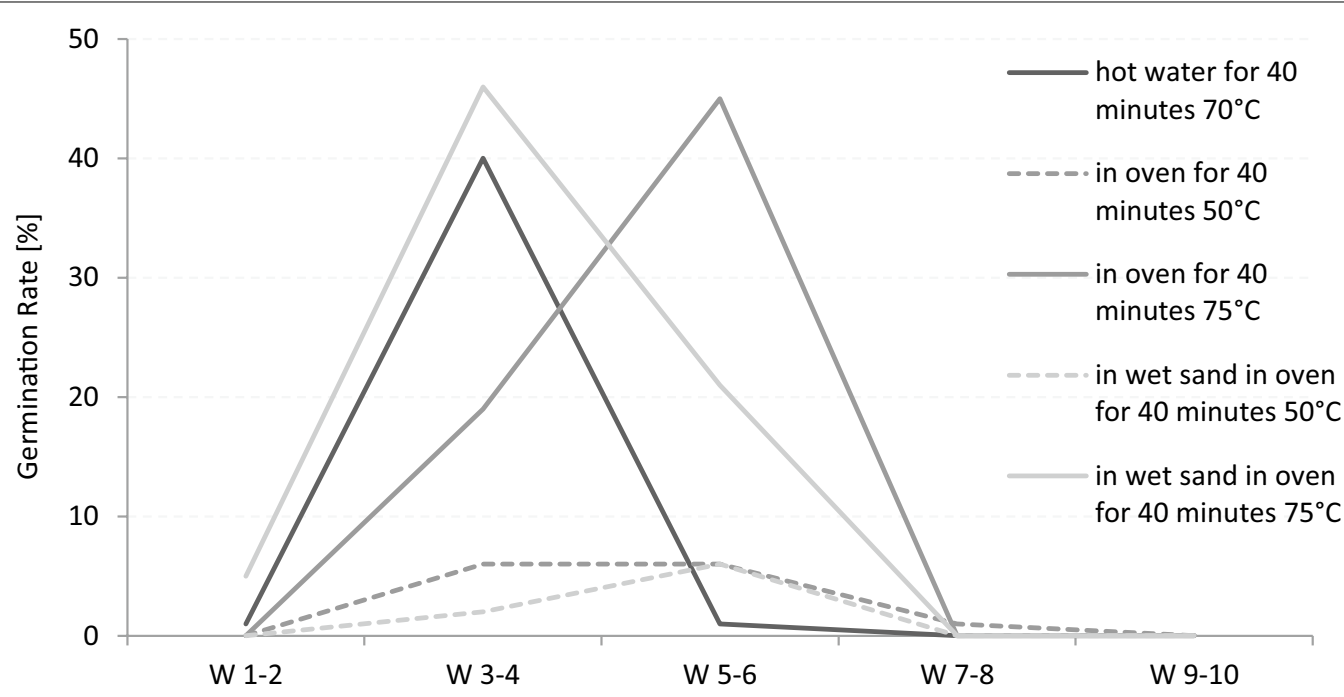

Fig. 1 Adansonia digitata seed-germination during 10 weeks (W) after heat treatment. Blue: $70^{\circ} \mathrm{C}$ hot water for 40 min. Red: Dry conditions in oven for $40 \mathrm{~min}$. Orange: Wet conditions in the oven for $40 \mathrm{~min}$. Dashed lines: $50^{\circ} \mathrm{C}$, solid lines: $75^{\circ} \mathrm{C}$
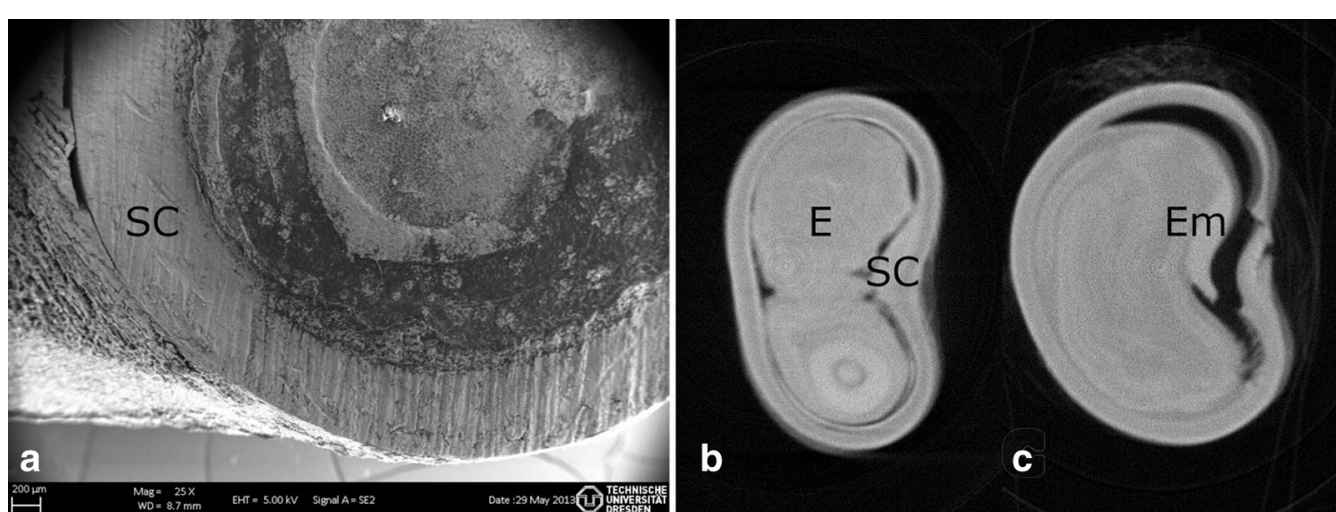

Fig. 2 Seed of Adansonia digitata. a SEM-picture of the firm testa with a thickness of $700 \mu m, E$ endosperm, Em embryo, SC seed coat; (b) and (c) tomography in lateral view: (b) dry untreated seed; (c) seed after immersion in water at $100^{\circ} \mathrm{C}$. Due to the swelling cavities disappear and seed coat cracks open on the inside of the reniform seed

filled with tannin (Rao 1954) (Figs. 3a and 4b). The tomographic images (Fig. 2b, c) illustrate the swelling process after treating the seed in water at $100{ }^{\circ} \mathrm{C}$. Due to the swelling, cavities between seed coat and endosperm disappear and the seed coat cracks open on the inside of the reniform seed where the embryo is located. Looking now closer to that inner cavity the palisade layer becomes thinner up to a certain point where it is interrupted by a small hole of $400 \mu \mathrm{m}$ in diameter, called chalazal oculus (Gama-Arachchige et al. 2013) (Fig. 3c). In untreated seeds, this opening is filled with the chalazal plug that provides the vascular supply for the embryo (Fig. 3a, b).

\section{Discussion}

\section{Ecological triggers}

Scarification by digestion, as exemplarily shown with elephants, showed only a small albeit significant increase of GR although acid treatment showed better results and therefore let suspect its positive influence on germination (Razanameharizaka et al. 2006; Kempe, Neinhuis and Lautenschläger 2018). The authors that detected a higher GR after acid treatment did not imitate the intestinal scarification process like we did here $(\mathrm{HCl}$ of $\mathrm{pH} 2$ and 3 for 1 or $2 \mathrm{~h}$ ). Studies with $\mathrm{HCl}$ treatment for $8 \mathrm{~h}$ revealed also a very low GR (Johansson 1999). As a consequence, elephants most probably serve as vectors for seed dispersal (Gerald and Wickens 1982) rather than for breaking 

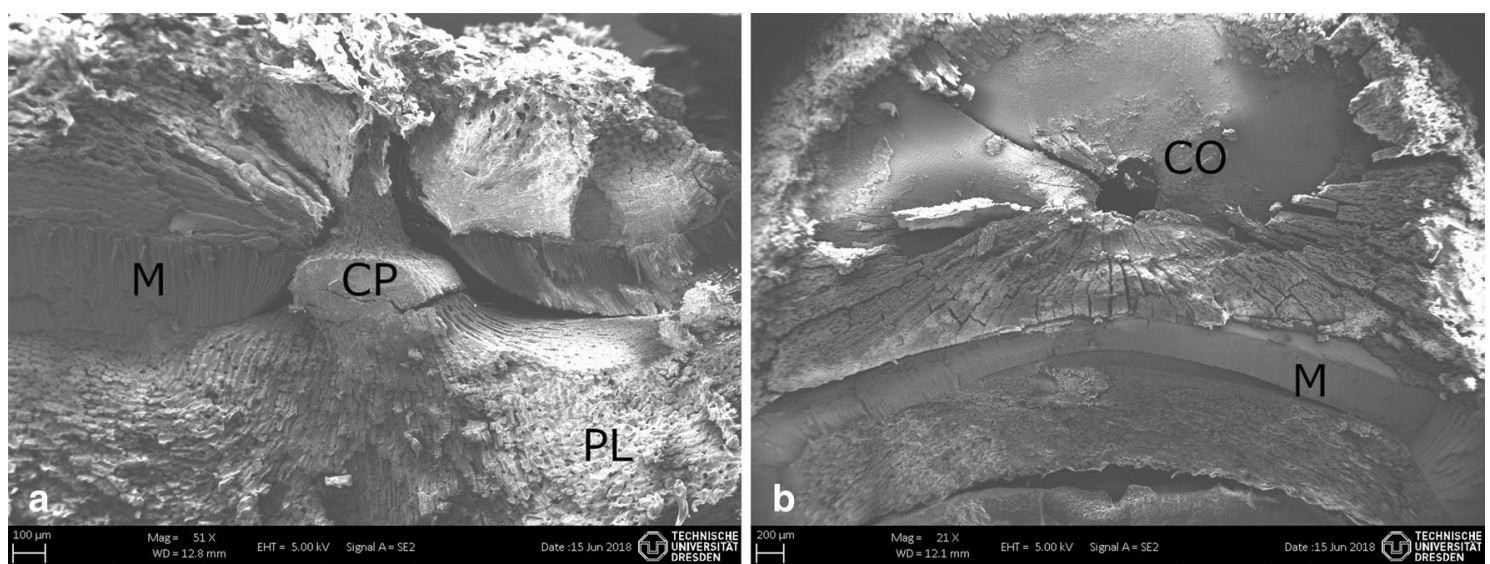

Fig. 3 SEM-pictures of germination mechanism of Adansonia digitata seed at the chalaza, CO chalazal oculus, CP chalazal plug, M Malpighian cells, $P L$ inner pigment layer with tannin. a side view of the chalazal plug; $\mathbf{b}$ top view on the chalazal oculus after removing the plug
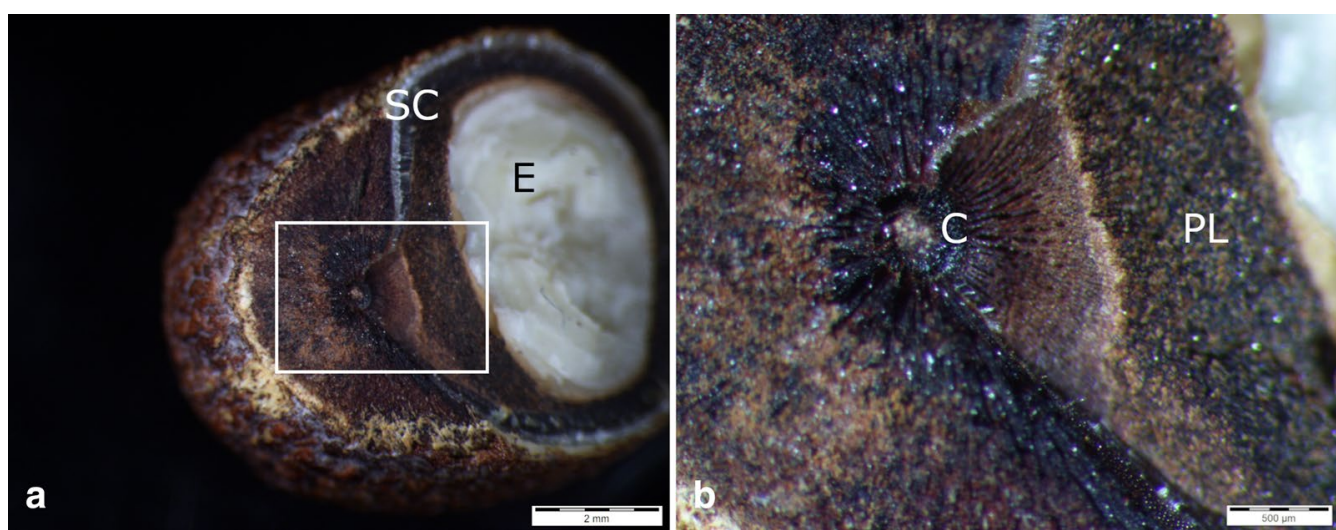

Fig. 4 Incident-light microscopy images of Adansonia digitata seed, at the inner surface of the reniform seed, C chalaza, E endosperm, PL inner pigment layer with tannin, SC seed coat. a Seed fracture to bare the chalaza; $\mathbf{b}$ close-up view of the chalaza structure

seed dormancy. It even seems that digestion can reduce the germination success, visible in the comparison of GR between seeds with or without digestion before heat treatment.

In contrast, not only the treatment with hot water but also the treatment with hot air showed significantly higher GRs. Since the best results were obtained after exposure to a temperature of $75^{\circ} \mathrm{C}$ for $40 \mathrm{~min}$ and 100 ${ }^{\circ} \mathrm{C}$ for $5 \mathrm{~min}$ possible triggers could be high radiation to the savanna soils or wildfires. High solar radiation leads to soil temperatures up to $60^{\circ} \mathrm{C}$, measured in a soil depth of $1.3 \mathrm{~cm}$ in North Australia with an equivalent degree of longitude of $14^{\circ} \mathrm{S}$ (Kalma 1971), or in Niger, $13^{\circ} \mathrm{N}$ (Vandenbeldt and Williams 1992). In deserts, soil surface temperatures may even exceed $70{ }^{\circ} \mathrm{C}$ (Belnap 2003). For northern Angola, we measured soil temperatures of maximum of $32{ }^{\circ} \mathrm{C}$, only during the very cloudy rainy season. For a duration of several weeks or months, this continuous heat might have an influence on the scarification of the seed testa. On the other hand, Kempe et al. (2018) already mentioned the positive impact of savanna fires on germination. Here, the fruit shell of $A$. digitata was shown to serve as a suitable protection of the seeds from the heat generated by savanna wildfires. The moderate heat inside the fruits even improved germination of seeds that were extracted from the fruits. Several authors already discussed the breaking of seed dormancy by means of high temperatures caused by fires. Both, positive impacts on leguminous species (Bradstock and Auld 1995) and negative impacts on weed species (Egley 1990) were observed. Furthermore, studies in Mediterranean fire-prone ecosystems suggest that germination is more successful after the treatment with a single high temperature peak than after a heat treatment simulating summer temperature fluctuations in this area (Moreira and Pausas 
2012). Relating to our study, heat generated by fire seems to be the most probable trigger.

\section{Seed morphometrics}

Compared to published data on A. digitata seed morphometrics, the Angolan seeds with an average length of $12.0 \mathrm{~mm}$ are comparatively large. For Senegal, seeds with a length of only 10.7-11.3 mm (Razanameharizaka et al. 2006) and 10.4-11.4 mm (Niang et al. 2015) were measured. The same applies to the 100-seed dry weight. For the seeds collected in Angola we obtained $53.75 \mathrm{~g}$ while Razanameharizaka et al. (2006) recorded a weight of only 39.7 to $42.7 \mathrm{~g}$ and Niang et al. (2015) detected 34.15 to $50.59 \mathrm{~g}$. Both studies described the influence of precipitation as well as edapho-climatic environments on seed weight. Accordingly, higher rainfalls cause higher seed weights. Indeed, the annual precipitation in Angola is about $1000 \mathrm{~mm}$ while in Senegal it is below $700 \mathrm{~mm}$ (Barrientos and Soria 2020). On the other hand, seed size seems to influence germination rate, with smaller seed sizes yielding higher germination rates (Niang et al. 2015). This would explain why in our study, regardless of treatment, GR never exceeded $78 \%$ in contrast to various other studies (Esenowo 1991; Johansson 1999; Razanameharizaka et al. 2006; Niang et al. 2015). In addition, our positive control (manual nicking treatment) generated a similar result of $74 \%$. The GR reached in the tests with high temperature therefore correspond with the maximum expected GR. Furthermore, variation within the population or even an individual plant may be important for breaking seed dormancy as well. Seeds of some individuals germinate after heating at low and others at high temperatures (Liyanage and Ooi 2015). This might be another reason for the limited GR in our setups.

\section{Visualization of testa and germination process}

In Malvaceae, to which the baobab belongs, the chalazal slit is known to be capable of preventing water penetration at the stage of dehydration (Egley et al. 1985) but during germination, it probably represents the primary site of water entry, as it was found for various species (Werker 1997; Gama-Arachchige et al. 2013) and could be proven in this study. On the other side, it was observed that after heat treatment, differential thermal expansion separates the macrosclerid cells of the palisade layer, permitting water to penetrate (Rolston 1978). The latter could not be observed here.

Rao (1952) observed a high amount of tannin in between the chalazal cap and the embryo (Figs. 3a and 4b). Tannins are phytochemicals, which exhibit central functions like protection against ultraviolet radiations, pathogens and predators and contribute to physiological functions such as seed maturation and dormancy
(Halloin 1982; Shirley 1998; Pourcel et al. 2007). Rao and Deosthale (1982) showed that after soaking seeds in water overnight, $50 \%$ of the tannin was lost, while cooking even resulted in a $70 \%$ decrease. On the other hand, Harris and Burns (1970) described that high tannin hybrids of Sorgum showed a significantly lower seed germination than low tannin hybrids. A correlation between tannin content and germination success therefore can be deduced from these studies. In addition, temperature was mentioned to influence the tannin content. Makkar and Becker (1996) demonstrated that the recovery of tannins decreases with the increase of temperature. Another study found tannin fractions in the seat coat of wheat to be heat labile and described it as naturally occurring inhibitors, which affect the dormancy (Miyamoto, Tolbert and Everson 1961). Adding the results to these former findings on tannin inhibiting effects and its instability with increasing temperature, we presume that $A$. digitata seeds are well adapted to fire-prone savanna areas.

\section{Conclusion}

Our study showed that both, high solar radiation as well as moderate fires are possible triggers for the successful germination of Adansonia digitata seeds while the digestive tract of elephants plays an only minor role in removing inhibiting factors. The highest germination rate was achieved with a temperature of $100^{\circ} \mathrm{C}$ for $5 \mathrm{~min}$, followed by a treatment with $75^{\circ} \mathrm{C}$ for $40 \mathrm{~min}$.

The high amount of tannins in the chalazal region of the seed is considered to be the inhibiting factor of germination. Increasing temperatures lead to a decrease of tannin contents and therefore to germination. The tree is therefore not just well adapted to fire-prone savannas but the success of germination depends strongly on heat, provoked by wildfires or prolonged exposition to the sun.

\section{Supplementary information}

Supplementary information accompanies this paper at https://doi. org/10.1186/s40529-020-00296-0.

Additional file 1: Figure S1. Relative germination rate in percentage of Adansonia digitata seeds treated with acids and digested by elephants. Observation time: 10 weeks (W). Control experiments marked in green. Figure S2. Relative germination rate in percentage of Adansonia digitata seeds after digestion of elephants and exposed to heat for $5 \mathrm{~min}$.

Observation time: 10 weeks (W). Control experiments marked in green. Figure S3. Relative germination rate in percentage of Adansonia digitata seeds exposed to heat for 5 min. Observation time: 10 weeks (W). Control experiments marked in green. Figure $\mathbf{S 4}$. Relative germination rate in percentage of Adansonia digitata seeds exposed to heat for $40 \mathrm{~min}$. Observation time: 10 weeks (W). Control experiments marked in green. 


\section{Abbreviations}

A: Adansonia; C: Celsius; $\mathrm{GR}$ : Germination rate; $\mathrm{H}_{2} \mathrm{SO}_{4}$ : Sulfuric acid; $\mathrm{HCl}$ : Hydrochlorid acid; N: North; S: South; SEM: Scanning electron microscope.

\section{Acknowledgements}

Open Access funding by the publication fund of the TU Dresden. We are grateful to Wolfgang Ludwig and the staff of the Zoological Garden Dresden who made it possible to feed the elephants. With best thanks also to the gardeners Dirk Fietsch, Karin Schwabe and Joseph Gogollok of the Botanical Garden of the TU Dresden for supporting the germination tests, irrigating as well as for documenting germination events. Thanks to Hannah Tuchel for supporting the test settings in 2017 as well as Augustine and Alma Lautenschläger for the support in 2018. We are also grateful to Andreas Kempe and Matthias Rudolf for helping with statistical analysis. Gesine Schäfer and Christoph Baumbach from the Institute of Structural Physics, TU Dresden provided the tomography pictures. Thank you to Oliver Zierau and Carolin Boehlke for providing valuable literature on elephants' digestion. The authors also thank the administration and the staff of the University of Kimpa Vita in Uíge for logistical support during the fieldwork in Angola. The fieldwork in Angola was supported by a travel fund from the German Academic Exchange Service (DAAD). These published results were obtained in collaboration with the Instituto Nacional da Biodiversidade e Áreas de Conservação (INBAC) of the Ministério do Ambiente da República de Angola.

\section{Authors' contributions}

TL carried out fieldwork, analysed the collected data and drafted the manuscript. NT helped to design and conduct the germination tests. MG prepared the REM pictures. CN participated in the design of the study and helped to draft the manuscript. All authors read and approved the final manuscript.

\section{Authors' information}

Since 2012 the Universidade Kimpa Vita in Uíge, Angola and the Technische Universität Dresden, Germany, have a multifaceted cooperation including the establishment of a Botanical Garden with the focus on local medicinal plants as well as biodiversity assessments.

\section{Funding}

The program "Strategic Partnerships" of the TU Dresden as well as the Universidade Kimpa Vita supported the fieldwork in Angola.

\section{Availability of data and materials}

All data are available from the corresponding author.

\section{Ethics approval and consent to participate}

Not applicable.

\section{Consent for publication}

All authors have approved the manuscript and agreed with its submission to Journal of Botanical Studies.

\section{Competing interests}

The authors declare that they have no competing interests.

Received: 27 February 2020 Accepted: 6 June 2020

Published online: 16 June 2020

\section{References}

Barrientos M, Soria C (2020) The index mundi. https://www.indexmundi.com/ facts/indicators/AG.LND.PRCP.MM/compare\#country=ao:sn. Accessed 28 May 2020

Belnap J (2003) The world at your feet: desert biological soil crusts. Front Ecol Environ 1(4):181-189

Bradstock RA, Auld TD (1995) Soil temperatures during experimental bushfires in relation to fire intensity: consequences for legume germination and fire management in South-Eastern Australia. J Appl Ecol 32(1):76-84

Chevalier MA (1906) Les baobabs (Adansonia) de I 'afrique continentale. Bull la Société Bot Fr 53(6):480-496. https://doi.org/10.1080/00378 941.1906 .10831196
Corner EJH (1976) The seeds of dicotyledons. Cambridge University Press, London

Egley GJ (1990) High-temperature effects on germination and survival of weed seeds in soil. Weed Sci 4(5):429-435

Egley GJ, Paul RN Jr, Duke SO, Vaughn KC (1985) Peroxidase involvement in lignification in water-impermeable seed coats of weedy leguminous and malvaceous species. Plant, Cell Environ 8:253-260

ElBably SMZ, Rashed NM (2018) Influence of pregermination treatments on overcoming seed dormancy and seedling growth of baobab (Adansonia digitata L). Plant Prod Sci 45(2):465-476

Esenowo GJ (1991) Studies on germination of Adansonia digitata seeds. J Agric Sci 117:81-84

Gama-Arachchige NS, Baskin JM, Geneve RL, Baskin CC (2013) Identification and characterization of ten new water gaps in seeds and fruits with physical dormancy and classification of water-gap complexes. Ann Bot 112:69-84. https://doi.org/10.1093/aob/mct094

Gashaw M, Michelsen A (2002) Influence of heat shock on seed germination of plants from regularly burnt savanna woodlands and grasslands in Ethiopia. Plant Ecol 159:83-93

Gebauer J, EISiddig K, Ebert G (2002) Baobab (Adansonia digitata L.): a review on a multipurpose tree with promising future in the Sudan. Gartenbauwissenschaften 67(4):155-160

Gerald E, Wickens GE (1982) The baobab-Africa's upside-down tree. Kew Bull 37(2):173-1982

Halloin JM (1982) Localization and changes in catechin and tannins during development and ripening of cottonseed. New Phytol 90(4):641-657

Harris HB, Burns RE (1970) Influence of tannin content on preharvest seed germination in Sorghum. Agron J 62(6):835-836

International Seed Testing Association (ISTA) (1999) International rules for seed testing 1999. Seed Science and Technology Supplement. Bassersdorf, Switzerland: International Seed Testing Association

Johansson M (1999) The baobab tree in Kondoa Irangi Hills. Swedish University of Agricultural Sciences, Uppsala, Tanzania

Kalma JD (1971) The annual course of air temperature and near-surface soil temperature in a tropical savannah environment. Agric Meteorol 8:293-303

Kempe A, Neinhuis C, Lautenschläger T (2018) Adansonia digitata and Adansonia gregorii fruit shells serve as a protection against high temperatures experienced during wildfires. Bot Stud 59(1):7

Liyanage GS, Ooi MK (2015) Intra-population level variation in thresholds for physical dormancy-breaking temperatures. Ann Bot 116(1):123-131

Makkar HPS, Becker K (1996) Effect of pH, temperature, and time on inactivation of tannins and possible implications in detannification studies. J Agric Food Chem 44(5):1291-1295

McDonald JH (2015) Handbook of biological statistics. Sparky House Publishing, Baltimore

McGrew WC, Baldwin PJ, Marchant LF, Pruetz JD, Scott SE (2003) Ethnoarchaeology and elementary technology of unhabituated wild chimpanzees at Assirik. Senegal, West Africa. PalaeoAnthropology 1:1-20

Miranda AC, Miranda HS, Dias IDFO, de Souza Dias BF (1993) Soil and air temperatures during prescribed cerated fires in Central Brazil. J Trop Ecol $9(3): 313-320$

Miyamoto T, Tolbert NE, Everson EH (1961) Germination inhibitors related to dormancy in wheat seeds. Plant Physiol 36(6):739-746

Moreira B, Pausas JG (2012) Tanned or burned: the role of fire in shaping physical seed dormancy. PLoS ONE. https://doi.org/10.1371/journ al.pone.0051523

Niang M, Diouf M, Samba SAN, Ndoye O, Cissé N, Van Damme P (2015) Difference in germination rate of baobab (Adansonia digitata L.) provenances contrasting in their seed morphometrics when pretreated with concentrated sulfuric acid African. J Agric Res 10(12):1412-1420

Pourcel L, Routaboul JM, Cheynier V, Lepiniec L, Debeaujon I (2007) Flavonoid oxidation in plants: from biochemical properties to physiological functions. Trends Plant Sci 12(1):29-36

Prenzlin H (2009) Lehrbuch der Tierphysiologie, 7th edn. Fischer

Rao CV (1954) A contribution to the embryology of Bombacaeae. Proc Indian Acad Sci B 39(2):51-75

Rao PU, Deosthale JG (1982) Tannin content of pulses: varietal differences and effects of germination and cooking. J Sci Food Agric 33(10):1013-1016 
Razanameharizaka J, Grouzis M, Ravelomanana D, Danthu P (2006) Seed storage behaviour and seed germination in African and Malagasy baobabs (Adansonia species). Seed Sci Res 16:83-88

Rolston MP (1978) Water impermeable seed dormancy. Bot Rev 44(3):365-396 Savadogo P, Zida D, Sawadogo L, Tiveau D, Tigabu M, Odén PC (2007) Fuel and fire characteristics in savanna-woodland of West Africa in relation to grazing and dominant grass type. Int J Wildl Fire 16(5):531-539

Shirley B (1998) Flavonoids in seeds and grains: physiological function, agronomic importance and the genetics of biosynthesis. Seed Sci Res 8(4):415-422

Trollope WSW (1984) Fire in savanna. In: de Booysen PV, Tainton NM (eds) Ecological effects of fire in South African ecosystems. Springer, Berlin, pp 149-175

Van Howen W, Prins RA, Lankhorst A (1981) Fermentative digestion in the African elephant. South African J Wildl Res 11(3):78-88
Vandenbeldt RJ, Williams JH (1992) The effect of soil surface temperature on the growth of millet in relation to the effect of Faidherbia albida trees. Agric For Meteorol 60(1-2):93-100

Werker E (1997) Seed anatomy. Encyclopedia of plants anatomy, Gebrüder Borntraeger

Wickens GE, Lowe P (2008) The baobabs, pachycauls of Africa. Springer Science \& Business Media, Madagascar and Australia

\section{Publisher's Note}

Springer Nature remains neutral with regard to jurisdictional claims in published maps and institutional affiliations.

\section{Submit your manuscript to a SpringerOpen ${ }^{\circ}$ journal and benefit from:}

- Convenient online submission

- Rigorous peer review

- Open access: articles freely available online

- High visibility within the field

- Retaining the copyright to your article

Submit your next manuscript at springeropen.com 